\title{
TYPES AND PATTERNS OF TERRITORY IN THE TRADITIONAL SETTLEMENT OF NGATA TORO
}

\author{
Fuad Zubaidi \\ Department of Architecture, Tadulako, Indonesia \\ e-mail: fhoead@gmail.com.com
}

\begin{abstract}
Territory in architecture is defined as a live organism's boundary to determine their demands, mark, and defend it. Territory for humans is not only limited physically and space but also related to emotional and cultural needs. Research about territories has not been specifically studied in contexts related to cultures that have specific characteristics. Based on this, research has a focus on developing theories on the types and patterns of territories in a traditional settlement. This research is naturalistic based on the theoretical framework that is built from the meaning of the results of several studies that have been conducted. In this research, the use of case studies is used as an empirical study to see how phenomena in real life of society, especially at the boundary of phenomena with existing contexts. Case Study uses a single embedded case that has more than one analysis unit. The research location is in "Ngata Toro, To-Kulawi", which is a traditional settlement that has character and characteristics. The expected outcome of this research is to develop and build concepts of patterns and types of spatial territories in architecture related to behavioral and cultural aspects.
\end{abstract}

Keywords: patterns, types, territories, traditional settlements

\section{INTRODUCTION}

The territory is the formation of an area to achieve optimal privacy that is sought by developing physical settings, (Altman 1975). Types and levels of privacy are influenced by behavior patterns in the cultural context, personality, and aspirations of individuals Edney (1976). Walls, screens, symbolic boundaries, and tangible boundaries, as well as distance, are mechanisms for showing privacy.

Rapoport (2005), studying human relations, architecture, and culture is easier and more interesting to do for people who still hold their traditions because they are more homogeneous and clearer about their cultural role in the built environment. Besides that, learning about local ethnic architecture is the same as turning on plant plasma, the more diverse the more sustainable, the more diverse the cultural elements the more sustainable the culture. 
Lang (1987), "We have little understanding of the changes in patterns of territorial behavior of groups over time, although we do have some anecdotal information". Lang (1987), states; "We have little understanding of how taste cultures have been structured and how they have changed over time". Lang's statement explained that understanding of changes in the territorial behavior patterns of a group over time was very little.

Rapoport (2005) further stated that the relationship between Environmental Behavior Study (EBS) and culture is very important to be studied and can be divided into two views; first, in identifying culture with several varied explanations, models, which ultimately have an overall role in architectural theory. Both have a closer relationship with environmental design how culture plays an important role in understanding user groups, in different environments and situations.

Research on the concept of territory, related to how patterns and types of territory are very interesting topics. Altman (1975), dividing the territory into three categories: primary, secondary and public territory. The category is very specific related to specific aspects of the culture of the community. Lyman and Scott (1967), make a territorial type classification, there are only two different types; interaction territories, and body territories.

Sharkawy 1979 in Lang (1987), states four types of territoriality; the attached territory, central territory, supporting territory, and peripheral territory. Porteus (1977), identified three interrelated levels of territoriality; personal space, home base (spaces that are actively maintained), and home range (behavior that is formed is part of people's lives). Brower (1976), differentiates territories into four types, namely: personal territory, community territory, community territory, and free territory.

In this research, the study of territorial behavior was carried out on a case study of traditional settlements that are still very attached to customs and traditions, namely the Ngata Toro settlement. Ngata Toro as a traditional settlement has been formed for centuries past and has created a community that has been established since pre-colonial times. In pre-colonial times, the Toro community, like the people in the surrounding villages, was a "Village Republic" in the true sense of autonomous social and political unity. "Ngata Toro" in the district of Sigi in Central Sulawesi province was chosen as the location for developing territorial concepts because it has several characteristics that are unique in terms of culture, customs, and environmental context.

\section{THEORY / RESEARCH METHODS}

\section{Functions of Territory}

The territory is an area formation to achieve optimal privacy by rearranging physical settings or moving to other regions. Altman (1975) states: "Personalization and ownership are designed to regulate social interactions and to help satisfy various social and physical motives. The defense response may sometimes occur when territorial boundaries are violated ". Personalization and ownership are designed to 
regulate social interactions and to help meet social and physical needs. Defensive responses sometimes occur when territorial boundaries are violated. The definition states the basic character of a territory which is about; Ownership and arrangement of places, Personalization or marking, Order or order to defend against interference, and Ability to function which covers the range of basic physical needs to cognitive satisfaction and aesthetic needs.

Lang (1987), formulates that territoriality has four main characters; Ownership or rights of a place, Personalization or marking of a certain area, The right to defend yourself from outside interference, and Regulator of several functions, ranging from meeting basic psychological needs to cognitive satisfaction and aesthetic needs. The concept of territory is the result of theoretical analysis of behavior and environment that can influence each other, according to Altman (1975), by regulating privacy, the territory can be used to regulate the consistency between what is achieved and what is desired. In the context of ethology, the territory can be seen as a mechanism to prevent aggression both individually or in groups.

Altman and Chemers (1984), describe human territoriality in several aspects, scales, types, and functions of territories in the following table:

Table 1. Aspect of Territory

\begin{tabular}{cccc}
\hline Actor & Scale & Types & Function \\
\hline Individual & Object & Primary & Identity \\
& & Personal \\
\cline { 3 - 3 } Small-Group & Room & Secondary & Social Regulation \\
Big Group & House & System \\
& Community & Pation & \\
\hline
\end{tabular}

From some definitions and scope of territorial theory, which are discussed and researched by several experts can be formulated that the territory is; bounded space occupied, as meeting the needs of individuals or groups, as a tangible or symbolic sign, as ownership of a maintained space, as a fulfillment of needs and status, and elements of ownership that tend to be defended or cause feelings of discomfort if the territory is violated by others.

In connection with the interesting approach, territory means reducing complexity and making life easier in responding to various interests such as the existence of territorial regulations (homeowners have one rule on the other, guests also have their own rules in their positions).

\section{Types of Territory}

Altman (1975), divides the territory into three categories associated with personal involvement, involvement, closeness to the daily lives of individuals or groups and frequency of use. The three categories are the primary, secondary and public territory. 
1. Primary territory: is an area that is owned, used exclusively, recognized by others, is controlled permanently, and becomes a major part of the daily activities of its inhabitants.

2. The secondary territory is an area that is not too used exclusively by a person or group of people who have a relatively wide area coverage, periodically controlled.

3. Public territory: is an area that is used and can be entered by anyone but he must comply with existing norms.

These three categories are very specifically related to the specific aspects of the culture of the people. When referring to the restrictions above, so-called private places are equivalent to primary territories while public places are equivalent to public territories. In line with Altman (1975), Lyman and Scott (1967), making a territorial type classification comparable to Altman, there are only two different types namely; interactional territories, and body territories. Interaction territory is aimed at temporal or momentary areas that are controlled by individuals or groups when interacting.

Hussein El-Sharkawy (1979) in Lang (1987), shows four types of territoriality that are useful in environmental design namely;

1. Attached territory, is a personal space that is owned by someone

2. Central territory, is the house, building with ownership

3. Supporting territory; semi-private and semi-public zones such as corridors, swimming pools, front gardens, back gardens

4. Peripheral territory; is a public space such as a shared sports field, and a city park.

Brower (1976) distinguishes territories into four types:

1. Personal territory; Personal territory is controlled individually or in groups. Group members are members who have a very close relationship such as a relationship due to marriage or relationships due to blood ties.

2. Community territory; Community territory is controlled by groups whose members sometimes change, but each member has gone through a screening process and sometimes an inauguration ceremony is held in accepting the member. This is done is to clarify the differences between group members and people outside the group.

3. Community territory; This territory is controlled by the general public and is open to the public, including public places such as a highway, and also places that are not public property such as waiting rooms in terminals, performance halls in theaters and so on. Prohibition and control are less free than previous types of ownership. This is done through rules or norms that come from the community, these regulations can be based on gender differences, age differences, or racial differences.

4. Free territory; This territory has no permanent residents, and the subject's existence is not under the prohibition or control of certain parties. The rules that guide behavior are self-determined or based on natural forces or because of moral norms. This territory is characterized by the absence of territorial signs and therefore restrictions or controls that arise are more due to the exploration and imagination of its inhabitants. 
Based on several existing theories, it can be concluded that the type of territory that has been developed by several authors such as Altman, Brower, and Sharkawy has similarities in terms of the area coverage area and the existing space control functions. Primary territories have high permanent ownership of space and are exclusion-controlled by several people and groups, spatial control mechanisms are carried out extensively, residents have complete control and violations of territorial boundaries are considered a serious threat.

Secondary territories have ownership cognition that is not owned by one individual, others can enter and see as a credible user, space control is controlled periodically.

The public territory has low ownership cognition, control is very difficult and residents can only see but cannot be owned and controlled exclusively by individuals or groups. Free territories developed have low ownership cognition and have no permanent residents or users.

\section{Territory and Traditional Settlement}

The concept of territory as a focus of study in the context of traditional settlements is a study aimed at the development of architectural theory, especially behavior theory. Based on the literature review conducted, it can be concluded that the study of territorial theory based on research that has been done is still in the context of a fixed and real boundary space, other matters relating to a fixed and unrestricted boundary space related to social and cultural systems of the community have not been much studied.

Haryadi (2010), explains that there are three that affect settlements, namely; religious values, behavior and culture, of these factors are focused on two factors, namely cultural factors and behavioral factors to be studied. Haryadi (2010), revealed that the territory, in the architecture of the environment and behavior is defined as the boundary where living organisms determine their demands, mark, and defend it, especially from the possibility of intervention from other parties. Territories are more than demands on an area spatially and physically, but also emotional and cultural needs.

The cultural and behavioral aspects are the focus in this research study aspect, the behavioral aspect is a dynamic relationship between setting and behavior while the cultural aspect comprehensively reviews how the cultural system, social system, and physical culture of the people in the "Ngata Toro" research area. The territories included in Personal space can be said to be a portable territory. This refers to the surrounding bubbles that define the distance between one another. Its dimensions are related to culture, and it is very important to understand because it explains about geographical space.

\section{Research Methods}

Research on the territories in the traditional settlement of "Ngata Toro", considers several main matters concerning the appropriateness of the disciplines of 
Architecture and other sciences (sociology, anthropology), conformity to the problems formulated, conformity with the research objectives, conformity with the contribution and novelty of research.

The focus and motivation of this research are to develop theories related to architectural disciplines, especially behavioral architecture and solve a problem or problem especially the problem of behavior and culture of spatial use in traditional settlements that are the target of theory development. This study uses a naturalistic qualitative approach based on the Grand Theory about territoriality and territorial behavior, settlement theory and the theory of community culture that are used to make observations and describe in the form of concepts to reveal existing data.

Case studies in traditional Ngata Toro settlements are used as empirical studies that examine phenomena in real-life communities.

\section{RESULTS AND DISCUSSION}

\section{Cultural Characteristics as territorial forming factors}

Ngata Toro as a traditional settlement as a research locus, has been formed for centuries and has established a community that has been established since pre-colonial times. The data in this study were generated by direct field research by the author in a naturalistic study over a period of approximately 3 years.

Ngata Toro is a community that has very strong traditional institutions and institutions. All social activities and socio-cultural institutions of the Ngata Toro community, including managing natural resources, pivot on cultural principles; Pekahowia, Hintuwu and Katuvua. Hintuwu and Katuvua are the two main values in social institutions. Pekahowia is an ideal value in the relations betwee man and God. Hintuwu is an ideal value in relations between human beings based on the principles of appreciation, solidarity, and deliberation. Katuvua is the ideal value in the relationship between man and his environment which is based on wisdom and harmony with nature.

Both values form the normative framework of social relations which are shared and shared to determine whether or not a particular action is appropriate, both related to social interaction between humans and nature. The ideal values are outlined in the customary law and court rules which guarantee these values are adhered to by the entire Ngata Toro indigenous community.

Enforcement of customary law is done last by Totua Ngata, who is an authoritative and effective functioning local leadership institution. In addition to Totua Ngata, in the Ngata Toro indigenous community Tina Ngata is also known as an indigenous woman figure who holds cultural authority. In the practice of community life, these two traditional institutions (Totua and Tina Ngata) together with maradika (the Ngata government) regulate Ngata Toro's community life.

Interaction between Ngata Toro communities, the role of Hintuvu culture as one of the basic pillars of society to regulate interaction among humans/community 
members are very influential. Here are some of the functions of Hintuvu in the Ngata Toro community:

1. The functions of Hintuvu; concerning the regulation of relations between community members, the resolution of disputes between them, including the implementation of traditional ceremonies and life cycles. The vision of the relationship between humans or Hintuvu:

1. Pomebila (mutual respect, mutual respect)

2. Mahingkau, Mome Panimpu (united, solidarity)

2. The functions of Katuvua which are implied in Hintuvu, involve the regulation of community members in interaction with the surrounding environment, especially in the utilization of natural resources.

3. Gagu functions exist, the management of traditional equipment which includes traditional buildings (Lobo), huro, tadulako, traditional clothing, traditional ceremonial equipment, art equipment, traditional games and natural resources contained in the customary forest.

4. Functions related to the problem of supervision and enforcement of customary law carried out by Tondo Ngata, both concerning katuvua or hintuvu.

The implementation of all the functions above is coordinated with Totua Ngata. The tools of Totua Ngata were chosen based on their devotion and understanding and mastery of customs (nopahu and hohora). Submitted in Ngata Polibu (village meeting) which was attended by the community then appointed and inaugurated. Coordination of the implementation and supervision of the functions and authorities above is carried out at the boy level.

Community values translated into existing behavior in the form of religious understanding, understanding of government duties, and upholding the values of adat are depicted on behavior;

1. Raponcurai; has the intention that adat is everything that underlies community behavior and becomes a base to sit (the basis) for all behaviors related to social relations.

2. Topo Parenta Rapongkurei; (the government as a base to stand) has the intention that in the actions and behavior of adherence to the existing rules in the government system the basic things that need to be upheld (established). Leaders with all their policies must be respected.

3. Ropoingkuka; (religion as direction) has the intention that all existing behavior must be based on the belief that the ruler of nature/god (topehai). Religion is made as a direction to act, to behave which must be made into local wisdom.

\section{Spatial Organization and Social Interaction}

Traditional settlements are often represented as places that still hold traditional and cultural values that are related to religious or religious values that are specific or unique to a particular society that is rooted in certain places also outside of historical determination. The settlement spatial pattern consists of three elements, namely space with its constituent elements (buildings and the surrounding space), order (formation) which has the meaning of composition and pattern or model of composition. 
Ngata Toro as a traditional settlement has the complexity of building elements and the surrounding space. Ngata Toro has a wealth of traditional buildings as a means to accommodate the needs of the Ngata Toro community. In addition to traditional buildings such as the Lobo, Bantaya, Baruga, Gampiri, Bolanca, Paningku, Noncu Ncuna / Noncu Lampa buildings, there are also several other buildings such as places of worship (mosques/churches), public buildings, village offices, and other buildings. In addition to these buildings, of course, a settlement can not be separated from residential housing as an inherent element in a settlement. Residential housing conditions, when viewed from the structure and condition of buildings, consist of several categories of buildings such as non-permanent, semipermanent and permanent buildings. When viewed from the division of stratification and building area, Ngata Toro housing residents are divided into three parts, namely, small houses, medium houses, and large houses.

Traditional buildings in Ngata Toro are reviewed from their use in community activities, generally divided into two parts according to sacred and non-sacred activities. For activities or community ceremonies that are sacred, the community uses the Lobo building to conduct Indigenous Libu. For non-sacred activities and deliberation activities which are more general, carried out in Bantaya or Baruga buildings. Whereas the Gampiri and Paningku buildings are symbols of the storage buildings. In addition to the building as an element of residential space in Ngata Toro, there are also other supporting spaces such as open space, space for community businesses, infrastructure space and settlement facilities.

\section{Local wisdom as a mechanism to regulate the territory}

Culture is the basic thing that becomes the direction and underlies all space for the activities of the Ngata Toro community. Custom slogans as in the motto; Ngata Toro "Maroho Ada Manimpu Ngata" with the meaning of upholding the custom of building villages is the basis in making all the rules related to land use. Customary sanctions are imposed when there is a violation of the utilization function on land that has been traditionally divided and decreased. Each space/land has its function which must not be violated, and if it is violated by customary rules such as Givu, Mogane, mompepoyu and several other rules must be applied without exception.

In terms of land use, customary law is a strong foundation as a rule and control mechanism for land use. The Ngata Toro indigenous people acquire existing land not through expropriation or taking land owned by another person or group of people without permission, but through a transaction and has strong validity according to customary law. The Ngata Toro indigenous people regulate the control of the use of ownership territories over natural resources in two categories, namely:

1. Common ownership rights (Katumpuia Hangkani);

Land and all-natural resources in the customary area (huaka) including village land are shared by all the Ngata Toro indigenous people including wana ngkiki, wana, and pangale with everything in it except damar which has been processed by people. These joint ownership rights may not be traded, leased to anyone. Collective / communal ownership rights are limited to uses that are regulated and determined by the Ngata Toro institution. 
2. Private ownership rights (Katumpuia Hadua);

Land and all-natural resources in certain areas can become private/individual property if it has been managed as agricultural land. Generally, this ownership is in the name of the first forest clearing there called "popangalea". All land is controlled through Popangalea is called "Dodoha". The other basic ownership is the result of purchase (raiadai), internal, gift (ahirara) and requested (perapi). Private property includes pahawa pongko, oma, balingkea, with everything in it and amber in wana.

The two components of ownership rights above are the customary rules which are strictly adhered to by the Ngata Toro indigenous people. Some things are prohibited by customary rules to be managed even in private ownership rights, namely those concerning Katuvua. Institutions that have an interest in this matter must sit together in consultation, both Maradika (Ngata Government), Totua Ngata (LMA), Tina Ngata (OPANT). And concerned must agree with matters relating to Katuvua, namely:

1. The state of the planned place to be cleared, whether the forest ranger gives the land to be cleared or not.

2. Call each other, to always pay attention to the upstream of the river and the steep slope (Taolo). The results of joint decisions are taken in deliberations.

3. Customs and culture do not justify cutting wood carelessly to be used as a concoction of the main house upstream of water or on a steep slope, even more so if the felled timber is sold and bought elsewhere.

For generations, the Ngata Toro indigenous people have been provided with a rule called Mopahilolonga Katuvua (taking care of nature wisely). According to this view, three elements of life have a reciprocal relationship, grow and multiply and support each other, namely: Humans (Tauna), Animals (Pinatuvua), and Plants (Tinuda).

These three interrelated elements are arranged through Hintuvu. In the ownership of land which is controlled by individuals or groups, all are regulated in such a way as in the hintuvu and katuvua adat rules as well as the rules applied by the Ngata government and the National Park Authority. The forest for the people of Toro is one of the natural resources from which raw materials are obtained for living needs or managed as a place of cultivation.

As a community that has a Ngata Toro ancestral tradition, it has customary policies that must be adhered to by its citizens in terms of utilizing natural resources. The provisions can be grouped into two, namely Toipetagi (prohibition) and Toipopalia (taboo).

\section{The traditional territorial pattern of Ngata Toro settlement}

Territorial patterns in the Ngata Toro are formed based on the existing hierarchy of space. The spatial hierarchy that forms the existing spatial structure is oriented towards the direction of settlement growth. Generally divided into seven zones of existing space and ends in a sacred zone where the Lobo building is located

Spatial distribution in sequence from the entrance to the Ngata Toro area, namely; first the Raopa zone, which serves as a marker zone or boundary when 
entering the Ngata Toro region. The Raopa zone or the so-called hamlet is the outermost part of the Ngata Toro traditional area, the inhabitants of Raopa do not want to be separated from the customary area, even though administratively the village area belongs to the administration of other regions.

Second, the zone of Bulu Kuku or which means hilly area which used to be a lot of bird endemic to nails called nail feathers. Initially, this zone was not populated but often the development of settlements, this zone is inhabited by Toro people who come from migrant descendants.

Third, the Lengko Uwe zone or which means the intersection or deviation to the river is a buffer zone. Lengko Uwe as access to the new settlements of Nente Baru residents and access to the river. Entering the Lengko Uwe zone, several boundary symbols and markers are met before starting to enter the next zone. Fourth, Nente Baru is a new settlement area in the area around the river. the Nente Baru zone is generally inhabited by migrants who join the Ngata Toro traditional area.

Fifth, the Kinta zone or the gate is called a marker to enter the secondary zone in the Bulu Lempe region. In the Kinta zone, there are general public buildings that are more general as a place for public activities in general. Sixth, Bulu Lempe zone or flat ground as a secondary zone before entering the Bola core zone. In this zone, there is the Bantaya building and the Guest House where guests stay before entering the Bola zone where the Lobo building is located.

Seventh, the Bola zone or referred to as residents as the most end zone and is considered the core zone as the initial area of Ngata Toro traditional settlement. In this zone, some buildings are sacred to Lobo and as a gate to enter the forbidden areas of Wana and Wana Ngkiki. (Figure1)

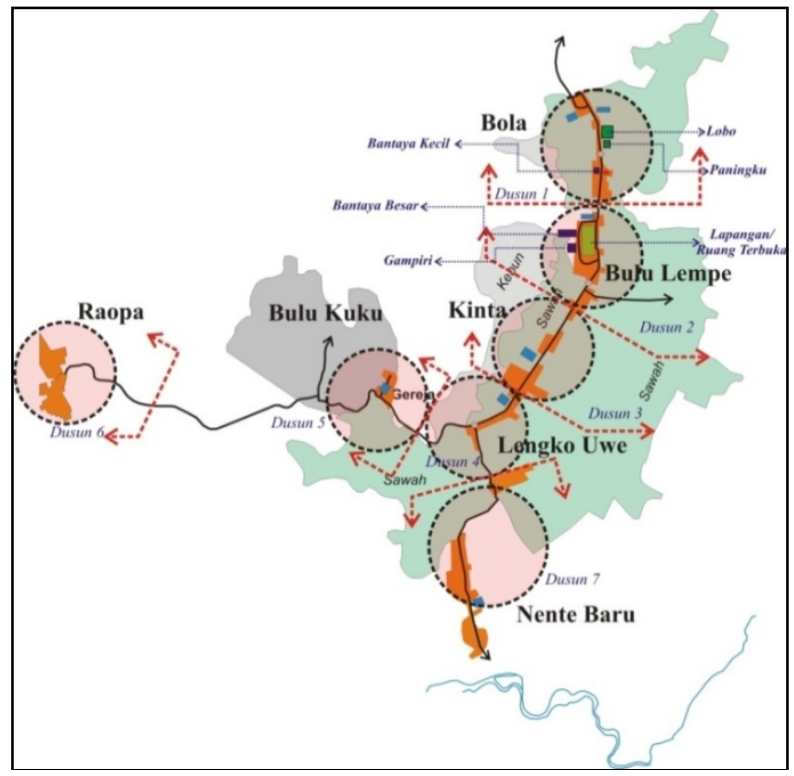

Figure 1. Territory Pattern Ngata Toro Traditional Settlement Source: Zubaidi, 2014 


\section{CONCLUSIONS}

From the results of this study several conclusions can be drawn as follows:

1. Territorial patterns as the basis for forming territorial types that exist in Ngata Toro traditional settlement settings in the form of one-on-one orientation. Based on the orientation patterns, there are differences in orientation patterns, in theory, there are orientation patterns in the form of facing, back to back, and unidirectional. It also enriches that in traditional settlements there are different territorial orientation patterns.

2. Type of territory, based on existing theoretical basis sourced from Altman $(1975,1984)$, Brower (1980), Porteus (1977), Sharkawy (1979), three types of territories were formulated namely; primary territory, secondary territory, and public territory. The three types of territories according to function, ownership, and control of existing territories. In the Ngata Toro traditional settlement setting, two new territorial categories were found; sacred territories, and indigenous territories. Based on the above it can be made comparative development of existing categories/types of territories based on existing theories and findings in the Ngata Toro traditional settlement settings.

3. Ngata Toro cultural factors in the form of Pekahowia, Hintuwu, and Katuvua influence the attitude of territoriality in territorial formation. Culturally there are differences in the attitude of these territories against the background of existing cultures based on situation and Personal factors.

\section{REFERENCES}

Altman, I. (1975) The Environment and Social Behavior, Monterey, CA: Wadsworth.

Altman, I. and Chemers, M. (1984) Culture and Environment, Monterey, California, Brooks Cole.

Altman, Rapoport, Wohlwill. (1980) Human Behavior and Environment, Advances in Theory and Research, Plenumm Press, New York.

Ardrey, R. (1970) The Territorial Imperative, New York, Atheneum.

Brower, S. N. (1976) Territory in Urban Settings, in Altman, (1980), Human Behavior and Environment, Plenary Press, NY, and London.

Gifford, R, (1987) Environmental Psychology, Principle and Practice, Boston: Allyn and Bacon. Inc.

Halim, D. (2005) Psikologi Arsitektur pengantar kajian lintas disiplin, Grasindo, Jakarta.

Haryadi, Setiawan, B. (1995) Arsitektur Lingkungan dan Perilaku, Proyek Pengembangan Pusat studi Dirjen Dekbud. Yogyakarta.

Koentjaraningrat. (2011) Pengantar Antropologi, Rineka Cipta, Jakarta.

Lang, J. (1987) Creating Architectural Theory: the Role of the Behavioral Sciences in Environmental Design, New York, Van Norstrand Reinhold.

Laurens, J. M. (2004) Arsitektur dan Perilaku Manusia, Grasindo, Surabaya

Porteous, J. D. (1977) Environment and Behavior, Addison Wesley Publishing Company, England. 
Rapoport, A. (1969) House Form and culture, Engelwood Cliffs, New York, Prentice-Hall. Inc.

Rapoport, A. (1977) Human Aspect of Urban Form, Pergamon Press, New York.

Rapoport, A. (1982) The Meaning of the Built Environment, A Nonverbal Communication Approach, Sage Publication.

Rapoport, A. (1986) The Use and design of open space in urban neighborhoods, di D Frick eds The Quality of urban life, Berlin

Rapoport, A. (2005) Culture, Architecture, and Design, Locke Science Publishing Company, Chicago

Sommer, R. (1983) Social Design: Creating Building with People in Mind, PrenticeHall Inc, New Jersey.

Tuan, Y. F. (1974) Topophilia: A Study of Environmental Perception, Attitudes, and Values New Jersey, Englewood Cliffs: Prentice-Hall.

Weissman, G. D. (1981) Modeling Environmental Behavior System, ABrief Nose, Journal of Man Environment Relation, Vol. 1. No. 2 The Pennsylvania State University.

Yin, R. K. (2003) Case Study Research; Design and Methods (Third Edition), Sage Publication, London.

Zubaidi, F. (2013) Territory in Traditional Settlement Context, Journal Psychology and Behavioral Sciences, Vol 2, pages 89-95, science publishing group.

Zubaidi, F. (2014) Culture Wisdom of "Ngata Toro" in the Establishment of Territory as an Effort to Maintain the Environment, International Journal of Education and Research, Vol 2-6, pages 23-36, Contemporary Research Center, Australia

Zubaidi, F. (2014) Concept Territory of Lobo Architecture "Ngata Toro", Social Sciences Journal, Vol 3-1, pages 17-22, science publishing group. USA 